
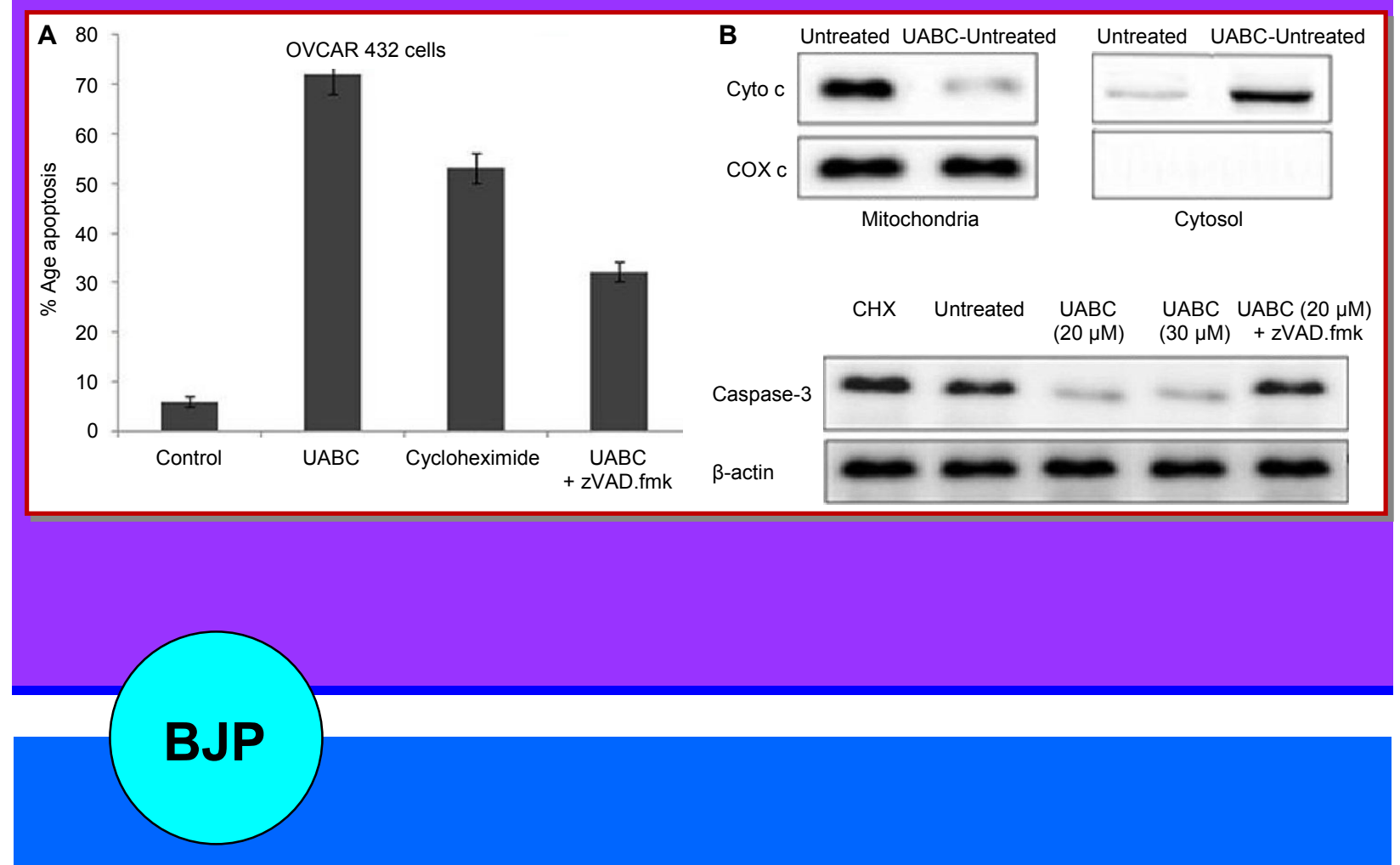

Bangladesh Journal of Pharmacology

Research Article

Ursolic acid benzaldehyde chalcone leads to inhibition of cell proliferation and arrests cycle in G1 / G0 phase in ovarian cancer 


\title{
Ursolic acid benzaldehyde chalcone leads to inhibition of cell proliferation and arrests cycle in G1/G0 phase in ovarian cancer
}

\author{
Yan Jia, Zan-Hui Jia, Jun Chen, He Zhu and Man-Hua Cui \\ ${ }^{1}$ Department of Obstetrics and Gynecology, The Second Hospital of Jilin University, Changchun, Jilin, 130 041 , China.
}

\begin{tabular}{|c|c|}
\hline \multicolumn{2}{|l|}{ Article Info } \\
\hline Received: & 27 January 2015 \\
\hline Accepted: & 14 March 2015 \\
\hline Available Online: & 22 April 2015 \\
\hline \multicolumn{2}{|c|}{ DOI: 10.3329/bjp.v10i2.21753 } \\
\hline \multicolumn{2}{|c|}{$\begin{array}{l}\text { Cite this article: } \\
\text { Jia Y, Jia ZH, Chen J, Zhu H, Cui MH. } \\
\text { Ursolic acid benzaldehyde chalcone } \\
\text { leads to inhibition of cell proliferation } \\
\text { and arrests cycle in G1/G0 phase in } \\
\text { ovarian cancer. Bangladesh J Pharma- } \\
\text { col. } 2015 ; 10: 358-65 \text {. }\end{array}$} \\
\hline
\end{tabular}

\begin{abstract}
In the present study, the effect of ursolic acid benzaldehyde chalcone (UABC) on ovarian carcinoma cells was studied. The results revealed that ovarian carcinoma cells on UABC treatment increased Sub-G1 cell population, increased rate of cell apoptosis and morphological changes in mitochondrial membrane. In OVCAR 432 cells treatment with UABC increased the Sub-G1 cell population to $72.3 \%$ and growth inhibition rate of $>72 \%$. Treatment with $20 \mu \mathrm{M}$ of UABC for 48 hours, led to an induction of apoptosis in $67.2 \%$ and induced morphological changes in OVCAR 432 cells. The Western blot results showed high concentration of cytochrome $\mathrm{c}$ in the cell cytosol after 48 hours of UABC treatment. Treatment of RMS-13 cells with UABC resulted in inhibition of GLI1, GLI2, PTCH1, and IGF2 genes. In addition, we found a significant reduction in hedgehog activity of RMS-13 cells after UABC treatment by means of a hedgehog-responsive reporter assay. Therefore, $\mathrm{UABC}$ can be a promising agent for the treatment of ovarian carcinoma.
\end{abstract}

\section{Introduction}

Ovarian carcinoma because of late stage detection is the most lethal gynecological malignancy. It is usually diagnosed after tumor cells are widely metastasized within the peritoneal cavity. In spite of advancement in modern cancer treatments like surgery and combination therapy with paclitaxel and carboplatin the death rate of patients is still high (Cannistra, 2004; Lengyel, 2010). All the treatments for ovarian carcinoma at present are inefficient. Radiation therapy has led to an average survival rate of 5 years in 10\% (Fuks, 1975; Dembo, 1984; Martinez et al., 1985; Fuks et al., 1987) while as chemotherapy has led to a response rate from 3 to $30 \%$ (Wiltshaw et al., 1986; Parker et al., 1980; Wharton et al., 1984; Williams et al., 1985; Louie et al., 1986). The patients with less than $25 \%$ and greater than $75 \%$ cytoreduction have an average difference in survival of 11 months (Bristow et al., 2001). Therefore, the need for new treatment regimens with roles in ovarian carcinoma treatment is highly desired. The 5-fluoro- uracil (5-FU) and oral fluoropyrimidines have been shown to be effective in many cancers including gastrointestinal tract cancers (Takiuchi et al., 1998). New generations of oral fluoropyrimidine such as S-1, which inhibit the degradation of 5-FU and capecitabine have been developed and put into use in the treatment of several solid tumors (Schoffski, 2004). 5-FU and 4HPR showed positive responses in combination with platinum based drugs or as a single agent in phase II trials respectively in ovary carcinoma (Rosa et al., 2008; Weiss, 1992; Garcia et al., 2004).

Ursolic acid, a pentacyclictriterpenoid present in abundance in apple peels (Liu, 1995) suppress tumorigenesis (Huang et al., 1994), inhibits tumor promotion (Tokuda et al., 1986; Ohigashi et al., 1986; Nishino et al., 1988) and angiogenesis (Sohn et al., 1995). Ursolic acid mainly exerts its anti-tumor effect by suppressing the expression of genes regulated by NFkB (Simon et al., 1995; Najid et al., 1992). Not only ursolic acid but its derivatives also induce apoptosis in a variety of cancer cells (Es-Saady et al., 1992;1996) 


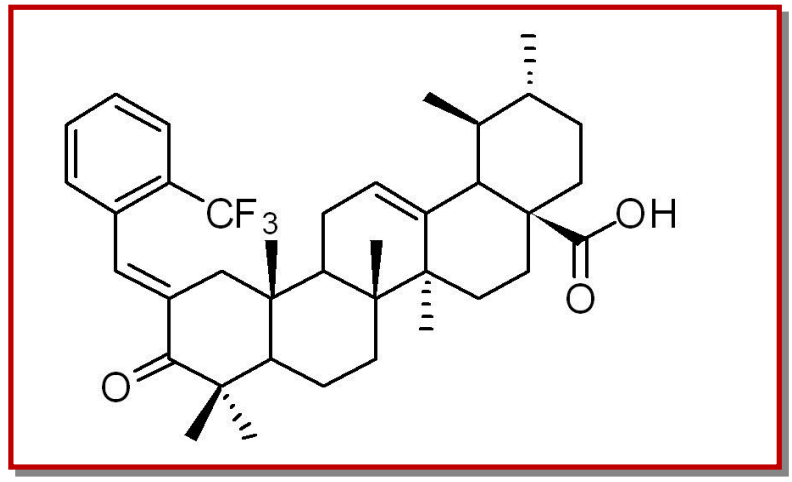

Figure1: Structure of ursolic acid benzaldehyde chalcone

through DNA replication inhibition (Kim et al., 2000), caspase activation, (Choi et al., 2000) and tyrosine kinases inhibition (Hollosy et al., 2000). In the present study we first time report the effect of ursolic acid chalcone (Figure 1) treatment of ovarian carcinoma.

\section{Materials and Methods}

\section{Chemicals}

Ursolic acid benzaldehyde chalcone was purchased from Sigma-Aldrich (St. Louis, MO, USA).L-glutamine from invitrogen (Carlsbad, CA, USA), 1\% penicillin and streptomycin from Gibco, (Grand Island, NY, USA). Enhanced chemiluminescence (ECL), nitro-cellulose membrane and ECL prime Western blotting detection reagents were obtained from GE Healthcare Life Sciences (Buckinghamshire, UK). Hoechst 33342, 3-(4,5dimethylthiazol-2-yl)-2,5-diphenylterazolium bro-mide (MTT), 1-methyl-4-phenylpyridinium (MPPp), dimethyl sulfoxide (DMSO) and $\beta$-actin were purchased from Sigma (St Louis, MO, USA).

\section{Cell culture}

The human ovarian cancer lines OVCAR 432, RMS-13 cell lines and NIH-3T3 fibroblasts were obtained from American Type of Collection centre (Manassas, VA, USA). The cells were maintained in minimum essential medium (MEM), containing $10 \%$ fetal bovine serum and antibiotics. The cell lines were maintained in a humidified incubator at $37^{\circ} \mathrm{C}$ and $5 \% \mathrm{CO}_{2}$.

\section{Cytotoxicity assay}

In 96-well culture plates $5 \times 10^{3}$ cells were plated per well in MEM. To each well $200 \mu \mathrm{L}$ containing different concentrations of UABC in DMSO was added and the plates were incubated for 24 hours at $37^{\circ} \mathrm{C}$. After 24 hours the medium was changed to drug free medium and incubation was continued for 5 days more. Alamar blue vital dye indicator assay (Ahmad et al., 1994) was used to measure the cell viability. Inhibition in cell growth is denoted as cytotoxicity and represented as concentration-response curve (surviving percentage versus drug concentration). The $\mathrm{IC}_{50}$ is determined from a least squares regression fit to the linear portion of the curve.

\section{Flow cytometry}

The cells distributed at a density of $8 \times 10^{5}$ onto $100 \mathrm{~mm}$ dishes were incubated at $37^{\circ} \mathrm{C}$ for 24 hours. After 24 hours, the cells were treated with UABC at $\mathrm{IC}_{50}$ concentration. Nuclear staining for DNA content was performed after harvesting the cells at 12, 24 and 48 hours from treatment. The untreated cells were also harvested at the same time points and used as control. The cells were treated with two solutions, a salt solution containing SDS and RNaseA, second solution containing sucrose and citric acid. Additionally both solutions contained ethidium bromide. Becton Dickinson FAC-Scan (cell Quest software) was used to acquire cell cycle data and Cell Cycle Muticycle (Phoenix Flow Systems, San Diego, CA) was used for analysis.

\section{Assessment of apoptosis}

The cells treated with UABC after harvesting were washed with PBS and fixed in formaldehyde at room temperature for $20 \mathrm{~min}$. Then fixative was removed and cells were suspended in $50 \mu \mathrm{L}$ of $8 \mu \mathrm{g} / \mathrm{mL}$ bisbenzimide trichloride dye (Hoechst-33258). On to the glass slides, $30 \mu \mathrm{L}$ cell aliquots were fixed. Five hundred cells were counted and scored for the incidence of apoptosis using fluorescence microscope. All the measurements were performed in triplicates.

\section{Western blot assay}

In 6-well plates $1 \times 10^{5}$ cells were platted per plate for 12 hours and then treated with UABC in the presence or absence of $50 \mu \mathrm{Mz}$ VAD.fmk. Vehicle treated cells were used as negative and cycloheximide (Sigma-Aldrich, Taufkirchen, Germany) as positive control. After 48 hours, cells were lysed in lysis buffer $(50 \mathrm{mM}$ Tris- $\mathrm{HCl}$ $\mathrm{pH} 7.4,137 \mathrm{mM} \mathrm{NaCl}, 10 \%$ glycerol, $100 \mathrm{mM}$ sodium vanadate, $1 \mathrm{mM}$ PMSF, $10 \mathrm{mg} / \mathrm{mL}$ aprotinin, $10 \mathrm{mg} /$ $\mathrm{mL}$ leupeptin, $1 \% \mathrm{NP}-40$, and $5 \mathrm{mM}$ cocktail) and the lysate was centrifuged to remove cell debris. Protein Assay System (Bio-Rad, Hercules, CA, USA) was used to determine concentration of proteins. The protein were loaded and resolved by electrophoresis on a $10 \%$ polyacrylamide gel and transferred to nitrocellulose membranes. The semidry method was used to transfer proteins onto a PVDF membrane which was then blocked with $5 \%$ non-fat dry milk overnight. Incubation of membranes with mouse anti-human caspase-3, rabbit antihuman cleaved caspase-3, rabbit antihuman $\beta$-actin (Cell Signalling Technology, Danvers, MA, USA), mouse anti-human COX4, rabbit antihuman cytochrome c (Clontech, Mountain View, CA, USA) or goat antihuman GLI1 (Santa Cruz Biotechnology, Santa 
Cruz, CA, USA) antibodies was performed for 2 hours. Then the incubation was continued for 1.5 hours with horseradish peroxidase-conjugated goat anti-rabbit, goat anti-mouse, or rabbit anti-goat IgG secondary antibodies (DakoCytomation, Hamburg, Germany). ECL chemilumine scence detection system (GE Healthcare) was used for visualising the signal.

\section{Hedgehog reporter and activation assays}

$5 \times 10^{5}$ RMS-13 cells or NIH-3T3 fibroblasts were transfected with $900 \mathrm{ng}$ of the reporter plasmid p11 $\mathrm{x}$ Gli or the empty control pGL3-TK (Beer et al., 2003) and $100 \mathrm{ng}$ of the reference plasmid pRL-TK using FuGene 6 transfection reagent (Roche Diagnostics). $1 \mu \mathrm{g}$ of an expression plasmid containing murine sonic hedgehog gene (Karolinska Institute, Stockholm, Sweden) was transfected into fibroblasts. After 24 hours transfection, cells were treated with UABC, $10 \mu \mathrm{M}$ cyclopamine (Toronto Research Chemicals, Toronto, Canada), or vehicle and cultured for 24 hours. A Dual-Glo Luciferase Reporter Assay System (Promega, Madison, Wisconsin, USA) was used for determination of reporter gene activity. Firefly luciferase activity was normalized to Renilla luciferase activity. After 24 hours of transfection total RNA was isolated using Trizol (Invitrogen) from fibroblasts.

\section{Statistical analyses}

The vehicle treated control cells were arbitrarily assigned $100 \%$ and other data were expressed in comparison to control. Data were analyzed by Dunnett's multiple comparison test (Sigma Stat, Jandel, San Rafael, CA, USA). For all comparisons, differences were considered statistically significant at $\mathrm{p}<0.05$.

\section{Result}

The cytotoxicity effect of UABC in OVCAR 432 cells was determined by cytometric analysis of Sub-G1 cell population. OVCAR 432 cells on treatment with various concentrations of UABC for different time periods exhibited cytotoxicity in a dose-and time-dependent manner. Among the range of concentrations $(5-30 \mu \mathrm{M})$
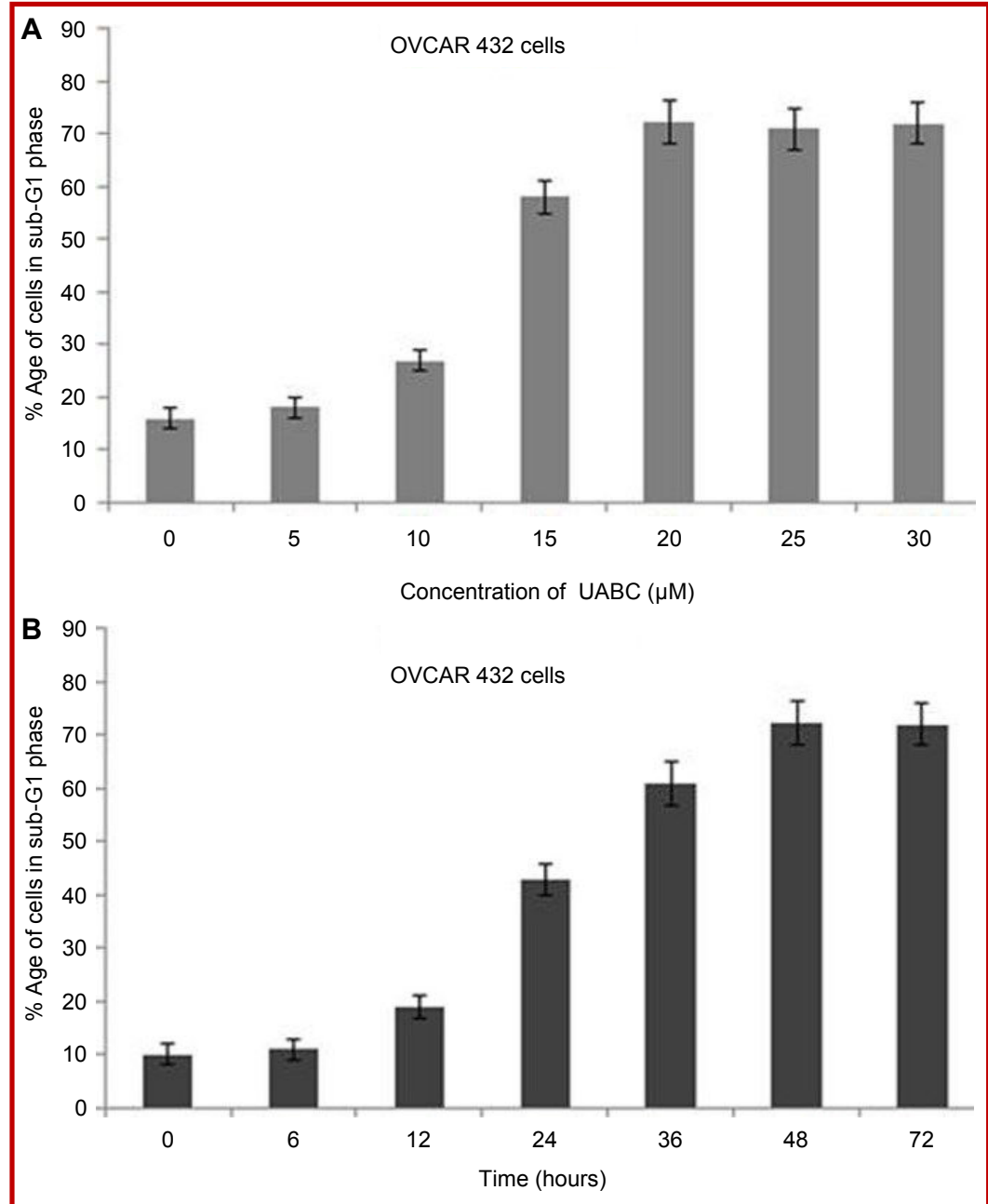

Figure 2: Cytotoxic activity of UABC against OVCAR 432 cells 


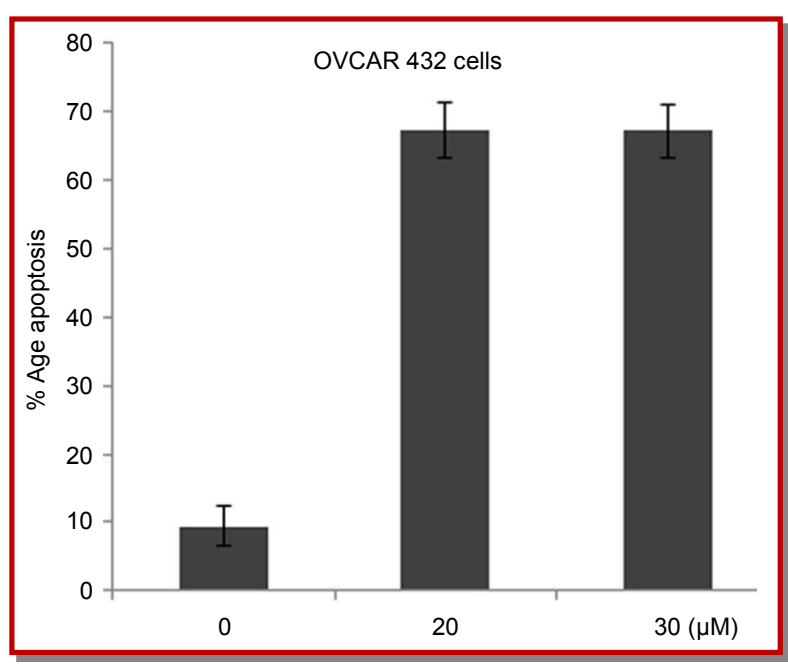

Figure 3: Rate of apoptosis in OVCAR 432 cells using quantitative fluorescence microscopy. All the results are mean of triplicate measurements

used, the cytotoxicity was significant at $20 \mu \mathrm{M}$ of UABC after 48 hours. In OVCAR 432 cells population of cells in Sub-G1 phase increased to $72.3 \%$ compared to only $16.2 \%$ in control (Figure 2).

We used quantitative fluorescence microscopy to observe apoptotic chromatin condensation in OVCAR 432 cells. The results of the analysis showed that UABC induces a higher rate of apoptosis compared to untreated control cells (Figure 3). Treatment of OVCAR 432 cells with $20 \mu \mathrm{M}$ UABC for 48 hours, caused an induction of apoptosis in $67.2 \%$ cells compared to $9.5 \%$ in control cells.

We also analysed the effect of UABC on morphological changes in OVCAR 432 cells. The results from flow cytometry showed that UABC induced significant rate of apoptosis after 48 hours. When OVCAR 432 cells were treated with UABC along with caspase inhibitor, zVAD.fmk there was inhibition in rate of apoptosis (Figure 4A). This indicated involvement of caspases in UABC-induced apoptosis. Therefore, UABC induces apoptosis through caspase dependent pathway.

The results from Western blot analysis showed high concentration of cytochrome $\mathrm{c}$ in the cell cytosol after 48 hours of UABC treatment. On the other hand cytochrome $\mathrm{C}$ concentration in the mitochondrial fraction inversely decreased (Figure 4B). Together, these results clearly indicate that UABC-induced apoptosis in OVCAR 432 cells is mediated by the intrinsic apoptotic pathway.

Treatment of RMS-13 cells with UABC resulted in inhibition of GLI1, GLI2, PTCH1, and IGF2 genes (Figure 5A). We did not observe any significant effect in two GLI1-negative RMS cell lines RH-30 and RD (Figure 5A). Moreover, we found a significant reduction in hedgehog activity of RMS-13 cells after treatment by means of a hedgehog-responsive reporter assay. To examine whether this inhibition is dependent on hedgehog signalling components upstream of GLI1, RMS-13 cells were treated with UABC in the presence or absence of $10 \mu \mathrm{M}$ cyclopamine, a specific hedgehog signalling inhibitor (Taipale et al., 2000). However, the inhibitory effect of UABC on GLI1 activity was found to be independent of cyclopamine treatment (Figure 5B), indicating that UABC is able to selectively target hedgehog signalling on the level of GLI1.

In order to activate hedgehog pathway in

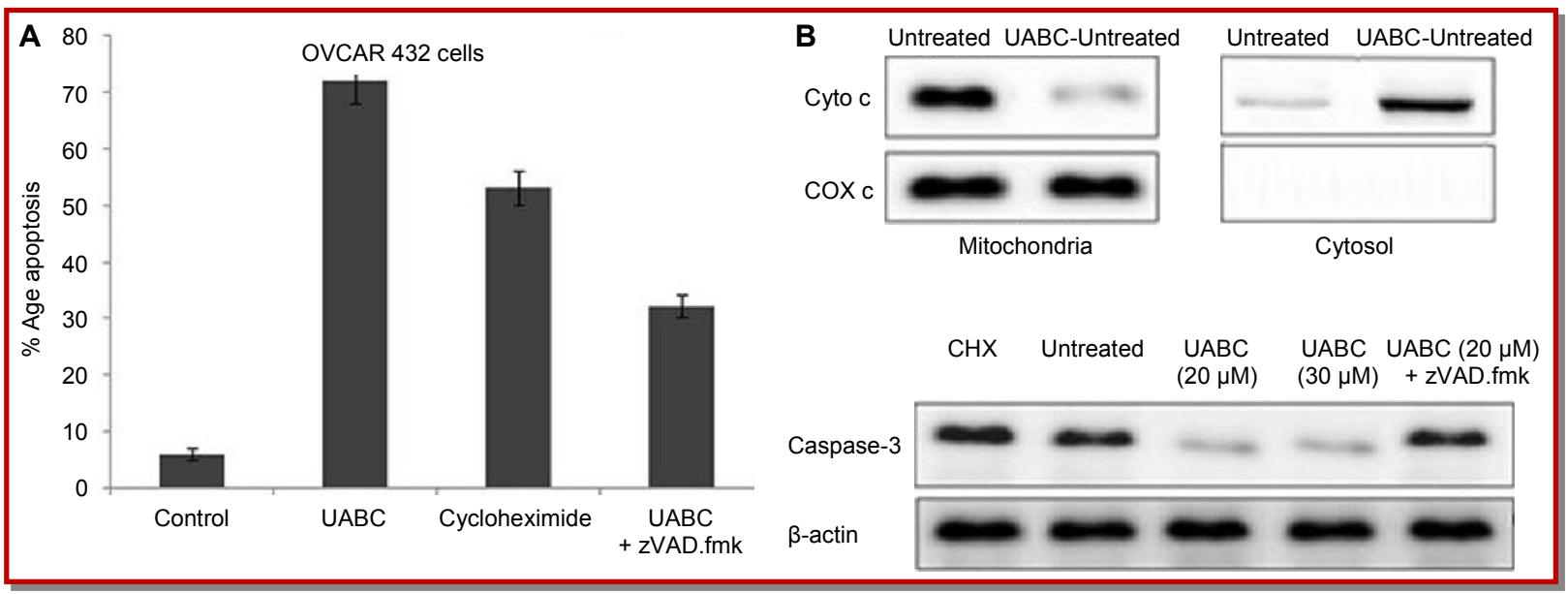

Figure 4: Effect of UABC on apoptosis in RMS cell lines. (A) The RMS cells were treated for $48 \mathrm{~h}$ with UABC in the presence or absence of $50 \mu \mathrm{M}$ of the zVAD.fmk. Apoptosis-specific DNA fragmentation was determined by FACS analysis of propidium iodide-stained nuclei; $100 \mu \mathrm{g} / \mathrm{mL}$ cycloheximide (CHX) was used as a positive control for apoptosis induction. (B) The RMS-13 cells were treated with UABC. Mitochondria were isolated, lysed, and the expression of cytochrome c and COX4 in the mitochondrial and cytosolic fraction was detected by western blot analysis. The RMS-13 cells were treated for 48 hours with UABC in the absence or presence of zVAD.fmk. Expression of caspase-3 and $\beta$-actin was detected by Western blot analysis. $100 \mu \mathrm{g} / \mathrm{mL}$ cycloheximide (CHX) was used as a positive control for apoptosis induction 


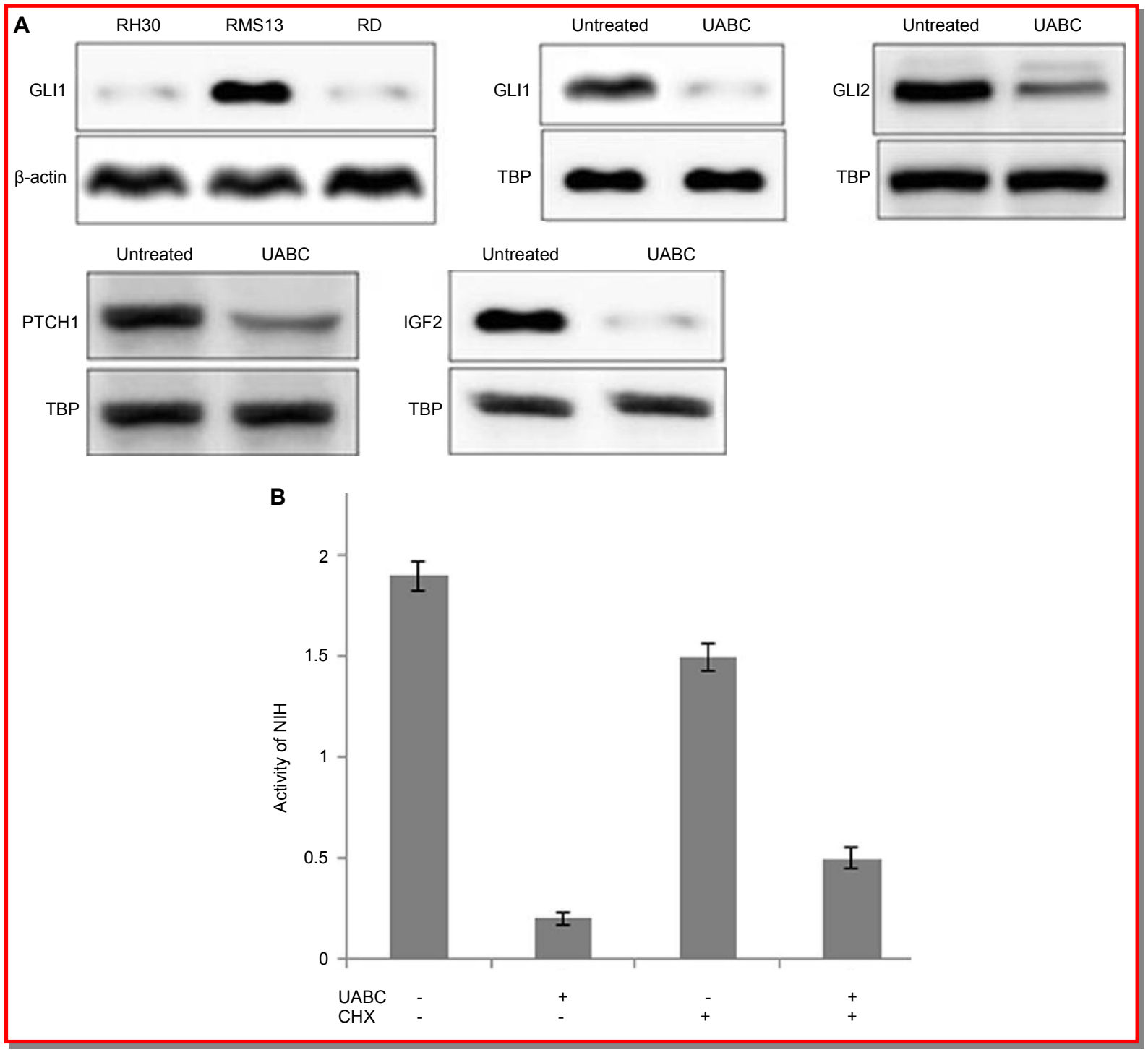

Figure 5: (A) UABC blocks hedgehog signalling, GLI1 expression of rhabdomyosarcoma cell lines. The RMS cell lines were lysed and the expression of GLI1 and $\beta$-actin was detected by western blot analysis. For hedgehog signalling dependency, the RMS cells were treated for 48 hours with UABC. GLI1, GLI2, PTCH1, and IGF2 mRNA expression from untreated and treated RMS cells was measured by quantitative real-time PCR in relation to the house-keeping gene TBP as a calibrator. (B) Hedgehog pathway activity. The RMS-13 cells were transiently transfected with 900 ng hedgehog-responsive reporter plasmid (p11 x Gli) or control plasmid (pGL3-TK) and treated for 24 hours with UABC and $10 \mu \mathrm{M}$ cyclopamine or vehicle. Reporter assay experiments were repeated three times and transfections performed in duplicate

untransformed NIH-3T3 cells, we expressed the ligand sonic hedgehog by transient transfection. This resulted in strong expression of the hedgehog target genes Gli1, Gli2, Ptch1, and Igf2 (Figure 6). But exposure to hedgehog inhibitor, cyclopamine resulted in inhibition of expression of these hedgehog target genes. The use of UABC led to inhibition of Gli1 and Gli2 expression with -out affecting Ptch1 and Igf2. These results led us to con -clude that UABC inhibits hedgehog signalling through GLI family transcription factors selectively.

\section{Discussion}

This study was carried out in order to investigate the potential of UABC in the treatment of ovary carcinoma. Angiogenesis has been reported as a prerequisite for tumor growth beyond certain size as well as for metastatic spread and, therefore, is an attractive target for clinical tumor biologists (Folkman, 2002). There are reports that anti-angiogenic treatments synergise with traditional chemotherapeutic and radiotherapeutic 


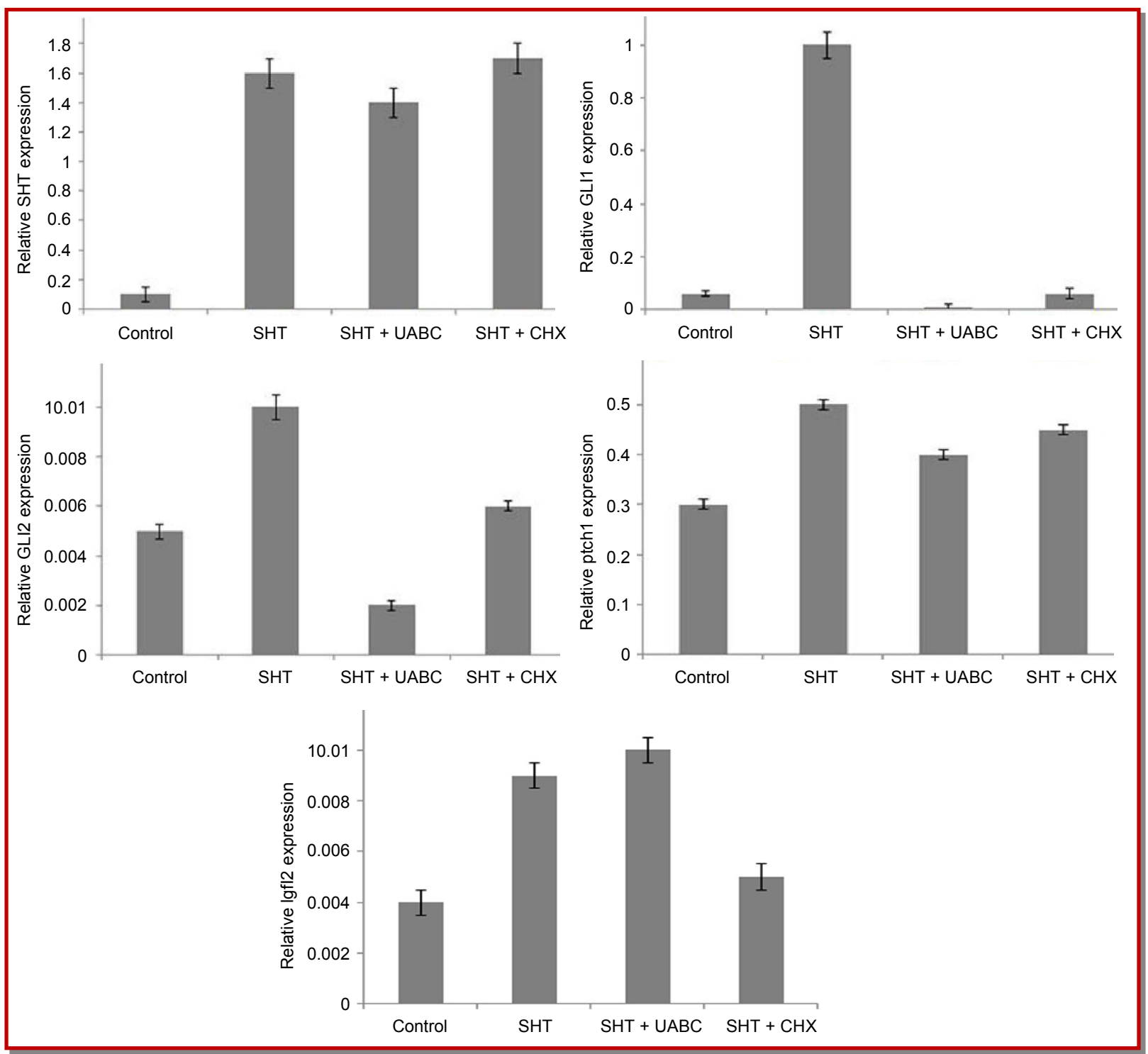

Figure 6: Hedgehog activation assay. The NIH-3T3 cells were transiently transfected with $1 \mu \mathrm{g}$ sonic hedgehog (Shh) expression plasmid. For the inhibition of hedgehog signalling, cells were additionally exposed to UABC and $10 \mu \mathrm{M}$ cyclopamine (CHX.) after 48 hours transfection. Expression of the murine genes SHT, Gli1, Gli2, Ptch1, and Igf2 was determined after an incubation period of 48 hours using quantitative real-time PCR in relation to the house-keeping gene TBP as a calibrator

regimens. Ursolic and betulinic acids not only exhibit cytotoxic effect against endothelial cells, but also inhibits tube-like structure formation of aortic endothelial cells (Kwon et al., 2002; Mukherjee et al., 2004). In the present study treatment of OVCAR 432 cells with UABC increased the Sub-G1 cell population to $72.3 \%$. The concentration of UABC that is effective in enhancing cytotoxicity is $20 \mu \mathrm{M}$ after 48 hours. Treatment of OVCAR 432 cells with $20 \mu \mathrm{M}$ UABC for 48 hours, induced apoptosis in $79.7 \%$ cells.

The purpose of the present study was to provide experimental evidence in order to help develop chemotherapeutic regimens for ovary carcinoma. The results from flow cytometry showed that UABC- induced apoptosis was significant after 48 hours. When the OVCAR 432 cells were treated with UABC along with caspase inhibitor zVAD.fmk, there was inhibition in rate of apoptosis. This led to the conclusion that caspases were involved in UABC-induced apoptosis. The Western blot results showed high concentration of cytochrome $\mathrm{c}$ in the cell cytosol after 48 hours of UABC treatment. On the other hand cytochrome $c$ concentration in the mitochondrial fraction inversely decreased.

Treatment of RMS-13 cells with UABC resulted in inhibition of GLI1, GLI2, PTCH1, and IGF2 genes. Moreover, we found a significant reduction in hedgehog activity of RMS-13 cells after UABC 
treatment by means of a hedgehog-responsive reporter assay. To examine whether this inhibition is dependent on hedgehog signalling components upstream of GLI1, RMS-13 cells were treated with UABC in the presence or absence of $7.5 \mu \mathrm{M}$ cyclopamine, a specific hedgehog signalling inhibitor (Taipale et al., 2000). However, the inhibitory effect of UABC on GLI1 activity was found to be independent of cyclopamine treatment, indicating that UABC is able to selectively target hedgehog signalling on the level of GLI1.

In conclusion, $\mathrm{UABC}$ has an important role in ovarian carcinoma treatment by inducing apoptosis through mitochondrial pathway and specifically targeting the hedgehog signalling pathway.

\section{References}

Ahmad SA, Gogal RM, Jr., Walsh JE. A new rapid and simple non-radioactive assay to monitor and determine the proliferation of lymphocytes: An alternative to $\left[{ }^{3} \mathrm{H}\right]$ thymidine incorporation assay. J Immunol Methods. 1994; 170: 211-24.

Beer C, Buhr P, Hahn H, Laubner D, Wirth M. Gene expression analysis of murine cells producing amphotropic mouse leukaemia virus at a cultivation temperature of 32 and 37 degrees C. J Gen Virol. 2003; 84: 1677-86.

Bristow RS, Tomacruz DK, Armstrong EL. et al. Survival impact of maximum cytoreductive surgery for advanced ovarian carcinoma during the platinum-era: A meta-analysis of 6,848 patients. Proc ASCO. 2001; 20: 202.

Cannistra SA. Cancer of the ovary. N Engl J Med. 2004; 351: 2519-29.

Choi YH, Baek JH, Yoo MA, Chung HY, Kim ND, Kim KW. Induction of apoptosis by ursolic acid through activation of caspases and downregulation of c-IAPs in human prostate epithelial cells. Int J Oncol. 2000; 17: 565-71.

Dembo AJ. Radiotherapeutic management of ovarian cancer. Semin Oncol 1984; 11: 238-50.

Es-Saady D, Simon A, Ollier M, Maurizis JC, Chulia AJ, Delage C. Inhibitory effect of ursolic acid on B16 proliferation through cell cycle arrest. Cancer Lett. 1996; 106: 193-97.

Es-Saady D, Simon A, Jayat-Vignoles C, Chulia AJ, Delage C. MCF-7 cell cycle arrested at G1 through ursolic acid, and increased reduction of tetrazolium salts. Anticancer Res. 1996; 16: 481-86.

Folkman J. Role of angiogenesis in tumour growth and metastasis. Semin Oncol. 2002; 29: 15-18.

Fuks Z. External radiotherapy of ovarian cancer: Standard approaches and new frontiers. Semin Oncol 1975; 2: 253-66.

Fuks Z, Yahalom Y, Brenner $H$. The treatment of ovarian carcinoma. In: Radiation therapy of gynecological cancer. Nori D, Hilaris BS (ed). New York, Liss, 1987, pp 147-72.

Garcia AA, Morgan R, McNamara M, Scudder S, Tsao-Wei D, Groshen S, Frgala T, Kim Y, Reynolds CP. Phase II trial of fenretinide (4-HPR) in recurrent ovarian and primary peritoneal carcinoma: A California Cancer Consortium trial.
J Clin Oncol. 2004; 22: 5056.

Hollosy F, Meszaros G, Bokonyi G, Idei M, Seprodi A, Szende B, Keri G. Cytostatic, cytotoxic and protein tyrosine kinase inhibitory activity of ursolic acid in A431human tumor cells. Anticancer Res. 2000; 20: 4563-70.

Huang MT, Ho CT, Wang ZY, Ferraro T, Lou YR, Stauber K, Ma W, Georgiadis C, Laskin JD, Conney AH. Inhibition of skin tumorigenesis by rosemary and its constituents carnosol and ursolic acid. Cancer Res. 1994; 54: 701-08.

Kim DK, Baek JH, Kang CM, Yoo MA, Sung JW, Chung HY, Kim ND, Choi YH, Lee SH, Kim KW. Apoptotic activity of ursolic acid may correlate with the inhibition of initiation of DNA replication. Int J Cancer. 2000; 87: 629-36.

Kwon HJ, Shim JS, Kim JH, Cho HY, Yum YN, Kim SH, Yu J. Betulinic acid inhibits growth factor-induced in vitro angiogenesis via the modulation of mitochondrial function in endothelial cells. Jpn J Cancer Res. 2002; 93: 417-25.

Lengyel E. Ovarian cancer development and metastasis. Am J Pathol. 2010; 177: 1053-64.

Liu J. Pharmacology of oleanolic acid and ursolic acid. J Ethnopharmacol. 1995; 49:57-68.

Louie KG, Ozols RF, Myers CE. Long-term results of a cisplatin -containing combination chemotherapy regimen for the treat -ment of advanced ovarian carcinoma. J Clin Oncol. 1986; 4: 1579-85.

Martinez A, Schray MF, Howes AE. Postoperative radiation therapy for epithelial ovarian cancer: The curative role based on a 24 year's experience. J Clin Oncol. 1985; 3: 901-22.

Mukherjee R, Jaggi M, Rajendran P, Siddiqui MJ, Srivastava SK, Vardhan A, Burman AC. Betulinic acid and its derivatives as anti-angiogenic agents. Bioorg Med Chem Lett. 2004; 14: 2181-84.

Najid A, Simon A, Cook J, Chable-Rabinovitch H, Delage C, Chulia AJ, Rigaud M. Characterization of ursolic acid as a lipoxygenase and cyclooxygenase inhibitor using macrophages, platelets and differentiated HL60 leukemic cells. FEBS Lett. 1992; 299: 213-17.

Nishino H, Nishino A, Takayasu J, Hasegawa T, Iwashima A, Hirabayashi K, Iwata S, Shibata S. Inhibition of the tumor promoting action of 12-O-tetradecanoylphorbol-13-acetate by some oleanane-type triterpenoid compounds. Cancer Res. 1988; 48: 5210-15.

Ohigashi H, Takamura H, Koshimizu K, Tokuda H, Ito Y. Search for possible antitumor promoters by inhibition of 12O-tetradecanoylphorbol-13-acetate-induced Epstein-Barr virus activation; ursolic acid and oleanolic acid from an antiinflammatory Chinese medicinal plant, Glechoma hederaceae L. Cancer Lett. 1986; 30: 143-51.

Parker LM, Griffiths CT, Yankee RA. Combination chemotherapy with Adriamycin-cyclophosphamide of advanced ovarian carcinoma. Cancer 1980; 46: 669-74.

Rosa DD, Awada A, Mano MS, Selleslags J, Lebrun F, Gil T, Piccart MJ, D'Hondt V. Oxaliplatin/5 fluorouracil-based chemotherapy was active and well tolerated in heavily pretreated patients with ovarian carcinoma. Arch Gynecol Obstet. 2008; 278: 457-62. 
Schoffski P. The modulated oral fluoropyrimidine prodrug S-1, and its use in gastrointestinal cancer and other solid tumors. Anti-cancer Drugs, 2004; 15: 85-106.

Simon A, Najid A, Chulia AJ, Delage C, Rigaud M. Inhibition of lipoxygenase activity and HL60 leukemic cell proliferation by ursolic acid isolated from heather flowers (Calluna vulgaris). Biochim Biophys Acta. 1992; 1125: 68-72.

Sohn KH, Lee HY, Chung HY, Young HS, Yi SY, Kim KW. Anti-angiogenic activity of triterpene acids. Cancer Lett. 1995; 94: 213-18.

Taipale J, Chen JK, Cooper MK, Wang B, Mann RK, Milenkovic L, Scott MP, Beachy PA. Effects of oncogenic mutations in smoothened and patched can be reversed by cyclopamine. Nature 2000; 406: 1005-09.

Takiuchi H, Ajani JA. Uracil-tegafur in gastric carcinoma: A comprehensive review. J Clin Oncol. 1998; 16: 2877-85.
Tokuda H, Ohigashi H, Koshimizu K, Ito Y. Inhibitory effects of ursolic and oleanolic acid on skin tumor promotion by 12 $o$-tetradecanoylphorbol-13-acetate.Cancer Lett. 1986; 33 ; 279-85.

Weiss RB. The anthracyclines: Will we ever find a better doxorubicin? Semin Oncol. 1992; 19: 670-86.

Wharton JT, Edwards CL, Rutledge FN. Long-term survival after chemotherapy for advanced epithelial ovarian carcinoma. Am J Obstet Gynecol. 1984; 148: 997-05.

Wiltshaw E, Evans B, Rustin G. A prospective randomized trial comparing high-dose cisplatin with low-dose cisplatin and chlorambucil in advanced ovarian carcinoma. J Clin Oncol. 1986; 4: 722-29.

Williams CJ, Mead GM, Macbeth RF. Cisplatin combination chemotherapy versus chlorambucil in advanced ovarian carcinoma: Mature results of randomized study. J Clin Oncol. 1985; 3: 1455-46. 